\title{
An Amphitropic cAMP-Binding Protein in Yeast Mitochondria. 1. Synergistic Control of the Intramitochondrial Location by Calcium and Phospholipid ${ }^{\dagger}$
}

\author{
Günter Müller*,‡ and Wolfhard Bandlow \\ Laboratorium für molekulare Zellbiologie und allgemeine Pathologie, Institut für Pathologie und Rechtsmedizin der Universität \\ Ulm, Neuherbergstrasse 11, D-8000 München 45, Federal Republic of Germany, and Institut für Genetik und Mikrobiologie der \\ Universität München, Maria-Ward-Strasse 1a, D-8000 München 19, Federal Republic of Germany
}

Received March 3, 1989; Revised Manuscript Received July 14, 1989

\begin{abstract}
A cAMP-binding protein is found to be integrated into the inner mitochondrial membrane of the yeast Saccharomyces cerevisiae under normal conditions. It resists solubilization by high salt and chaotropic agents. The protein is, however, converted to a soluble form which then resides in the intermembrane space, when isolated mitochondria are incubated with low concentrations of calcium. Phospholipids or diacylglycerol (or analogues) dramatically increases the efficiency of receptor release from the inner membrane, whereas these compounds alone are ineffective. Also, cAMP does not effect or enhance liberation from the membrane of the cAMP-binding protein. Photoaffinity labeling with $8-\mathrm{N}_{3^{-}}\left[{ }^{32} \mathrm{P}\right] \mathrm{cAMP}$ followed by mitochondrial subfractionation and sodium dodecyl sulfate-polyacrylamide gel electrophoresis does not reveal differences in the apparent molecular weight between the membrane-bound and the soluble form of the cAMP receptor. The two forms differ, however, in their partitioning behavior in Triton X-114 as well as in their protease resistance, indicating that the release from the membrane is accompanied by a change in lipophilicity and conformation of the receptor protein. Evidence is presented that a change of the intramitochondrial location of the yeast cAMP-binding protein also occurs in vivo and leads to the activation of a mitochondrial cAMP-dependent protein kinase. The cAMP-binding protein is the first example of a mitochondrial protein with amphitropic character; i.e., it has the property to occur in two different locations, as a membrane-embedded and a soluble form.
\end{abstract}

$\mathbf{S}_{\mathrm{e}}$ components, such as $\alpha$-actinin, gelsolin, profilin, spectrin, vinculin, and protein kinase $C$ have been found in recent years to occur in a membrane-associated form as well [e.g., Niggli and Burger (1987); for a review, see Burn (1988a)]. The reversible interaction of these proteins with the plasma membrane plays an important role in the fulfillment of their function in proliferation, the cell cycle, cell division and motility [for a review, see Geiger (1985) and Burridge (1986)]. It is controlled by the turnover of certain phospholipids in the membrane (Burn \& Burger, 1987; Burn, 1988b). For instance, upon hydrolytic generation of diacylglycerol in the plasma membrane the soluble $\mathrm{Ca}^{2+}$ - and phosphatidylserine-dependent protein kinase $\mathrm{C}$ becomes associated with the cytoplasmic side of the plasma membrane, with a concomitant decrease of the $\mathrm{Ca}^{2+}$ requirement for its activation [Kishimoto et al., 1980; for a review, see Nishizuka (1986)].

On the other hand, a variety of enzymes have been described, the greatest portion of which is tightly anchored in the membrane from which they can be released, most commonly, by a chemical modification or hydrolytic cleavage step. In this group are found, e.g., CTP:phosphocholine cytidylyltransferase (Kraft \& Anderson, 1983), calmodulin-dependent protein kinase type II (Bennet et al., 1983), and the selfprocessing protease calpain (Imajoh et al., 1986). These two groups of proteins belong to the newly defined class of amphitropic proteins.

Amphitropism of a protein is not only related to the regulation of its enzymic activity but may also alter its accessibility

\footnotetext{
${ }^{\dagger}$ This work was supported by a grant from the Deutsche Forschungsgemeinschaft to W.B.

* Address correspondence to this author at the Laboratorium für molekulare Zellbiologie und allgemeine Pathologie der Universität Ulm.

‡Universität Ulm.

¿niversität München
}

for other enzymes or substrates (e.g., calpain; Kishimoto et al., 1983) or may induce reorganization of the cytoskeletal architecture during elapse of the cell cycle (e.g., cytoskeletal linker proteins; Lassing \& Lindberg, 1985, 1988; Rotman et al., 1982). Thus, amphitropic proteins are assumed to be the heart piece of various regulatory events in transmembrane signaling by association with or dissociation from a membrane, thereby transmitting information from one compartment to the other.

There are only a few amphitropic proteins known which shuttle between the cytoplasm and cellular membranes other than the plasma membrane. CTP:phosphocholine cytidylyltransferase is recovered from both the cytosolic fraction and the endoplasmic reticulum of rat liver homogenates (Hershenson \& Ernst-Funberg, 1983), being inactive in the cytosol and active at the endoplasmic reticulum membrane (Terce et al., 1988). A cAMP $^{1}$-dependent protein kinase type II in MDBK cells is associated with centrosomes as well as with

\footnotetext{
${ }^{1}$ Abbreviations: PIP 2 , L- $\alpha$-phosphatidyl-D-myo-inositol 4,5-bisphosphate; $\mathrm{IP}_{3}$, D-myo-inositol 1,4,5-trisphosphate; PI, L- $\alpha$-phosphatidyl-D-myo-inositol; TPA, 12-myristoyl-13-acetylphorbol; $\mathrm{PH}, 4 \alpha$-phorbol; PHA, $4 \alpha$-phorbol acetate; PS, 1,2-dipalmitoyl-sn-glycero-3-phosphoserine; PC, 1,2-dipalmitoyl-sn-glycero-3-phosphocholine; P, 3-sn-phosphatidylserine; DAG, 1,2-dipalmitoyl-sn-glycerol; cAMP, adenosine $3^{\prime}, 5^{\prime}$-cyclic monophosphate; 8-N $\mathrm{N}_{3}$-cAMP, 8-azidoadenosine, $3^{\prime}, 5^{\prime}$-cyclic monophosphate; cGMP, guanosine $3^{\prime}, 5^{\prime}$-cyclic monophosphate; PEG, poly(ethylene glycol); SDS-PAGE, sodium dodecyl sulfate-polyacrylamide gel electrophoresis; DTT, dithiothreitol; EDTA, ethylenediaminetetraacetic acid; EGTA, ethylene glycol bis( $\beta$-aminoethyl ether)- $N, N, N^{\prime}, N^{\prime}$-tetraacetic acid; HEPES, $N$-(2-hydroxyethyl)piperazine$N^{\prime}$-2-ethanesulfonic acid; MES, 2-( $N$-morpholino)ethanesulfonic acid; MOPS, 3 -( $N$-morpholino)propanesulfonic acid; TEA, triethanolamine; Tris, tris(hydroxymethyl)aminomethane; PMSF, phenylmethanesulfonyl fluoride; IBMX, 3-isobutyl-1-methylxanthine; E-64, $N$-[ $N$-[(L-3-transcarboxy-2-oxiranyl)carbonyl]-L-leucyl]agmatin; NEM, $N$-ethylmaleimide; BSA, bovine serum albumin; Triton X-114, poly(ethylene glycol) mono(octylphenyl ether); PPO, 2,5-diphenyloxazole; POPOP, 1,4-bis(5phenyloxazol-2-yl)benzene.
} 
Golgi stacks (Nigg et al., 1985a), whereas the catalytic subunits, after dissociation from the regulatory subunits, migrate to the nucleus (Nigg et al., 1985b). The Sec4 protein of yeast is a ras-related, GTP-binding protein, synthesized as a soluble cytoplasmic protein. It becomes associated with the cytoplasmic face of both the plasma membrane and secretory vesicles during transit to the cell surface (Goud et al., 1988).

Up to now no amphitropic protein has been described in both the cytoplasm and mitochondria or in two different compartments of this organelle. In addition, little is known about signal transmission from the cytoplasm to mitochondria or within this organelle. Such a transfer of information would be expected to coordinate the biosynthetic activities of the nucleo/cytoplasmic and mitochondrial system which both cooperate in the biogenesis of mitochondria (Schatz \& Mason, 1974).

Here we describe an amphitropic protein in mitochondria of the yeast Saccharomyces cerevisiae. This protein (apparent molecular weight 46000 ) was previously demonstrated to bind cAMP specifically with high affinity (Rödel et al., 1985). It is tightly embedded in the inner membrane, the cAMP-binding domain facing the intermembrane space. In this study we provide evidence that phospholipids or diacylglycerol (or analogues) in the presence of $\mathrm{Ca}^{2+}$, at concentrations which do not affect the integrity of the inner mitochondrial membrane, causes the conversion of the membrane-bound cAMP-binding protein into a soluble form which is then localized in the intermembrane space. The releasing process is accompanied by a conformational change and a significant decrease in lipophilicity and is unlikely to involve proteolytic processing. The soluble form of the cAMP receptor may constitute the regulatory subunit of the cAMP-dependent protein kinase recently identified in the intermembrane space of yeast mitochondria (Müller \& Bandlow, 1987a).

\section{Materials and Methods}

Materials. Creatine kinase, cytochrome $c$, protease inhibitor E-64, $\alpha_{2}$-macroglobulin, 3',5'-cAMP, 3',5'-cGMP, ADP, AMP, creatine phosphate, MEGA 10, DTT, Triton X-114, $\mathrm{PIP}_{2}$, and $\mathrm{IP}_{3}$ were obtained from Boehringer, Mannheim; Sephadexes G-10 and G-25, Ficoll 400, Percoll, and ethylene glycol were provided by Pharmacia, Freiburg; Zymolyase 20000 was from Seikagaku Kogyo Co., Tokyo; acrylamide, $N^{\prime}, N^{\prime}$-methylenebis(acrylamide), ammonium persulfate, TEMED, SDS, POPOP, PPO, theophylline, bacitracin, $\mathrm{P}, \mathrm{PH}$, PHA, TPA, PS, PC, and DAG were obtained from Serva, Heidelberg; $\left[5,8{ }^{3} \mathrm{H}\right] \mathrm{cAMP}(52 \mathrm{Ci} / \mathrm{mmol})$ and $\left[\gamma^{-32} \mathrm{P}\right] \mathrm{ATP}$ (10-25 Ci/mmol) were provided from Amersham-Buchler, Braunschweig; $8-\mathrm{N}_{3}-\left[{ }^{32} \mathrm{P}\right] \mathrm{cAMP}(20 \mathrm{Ci} / \mathrm{mmol})$ was purchased from ICN, Eschwege; antipain dihydrochloride, aprotinin, leupeptin hemisulfate, pepstatin, PI, $\mathrm{PIP}_{2}, \mathrm{IP}_{3}, \mathrm{PEG} 4000$, benzamidine hydrochloride, BSA, HEPES, MES, MOPS, TEA, Tris, and IBMX were from Sigma, Taufkirchen; lactic acid was from Fluka, Neu-Ulm; mixed-ester cellulosic filters (HAWP, 24-mm diameter) were from Millipore, Eschborn; all other chemicals were bought from Merck, Darmstadt.

Yeast Strains and Growth Conditions. The experiments throughout this work were carried out with the protease-deficient yeast strains ABYS-66 (haploid) (Achstetter et al., 1984) and PEP4-3 (diploid) (Hemmings et al., 1981) or with the wild-type strain D273-10B as indicated. Cells, grown at $30^{\circ} \mathrm{C}$ in lactate medium (Daum et al., 1982) in the presence of $50 \mu \mathrm{g} / \mathrm{mL}$ adenine, $50 \mu \mathrm{g} / \mathrm{mL}$ uracil, and $25 \mu \mathrm{g} / \mathrm{mL}$ ampicillin, were harvested at a titer of $3 \times 10^{6} / \mathrm{mL}$.

Preparation of Mitochondria. Mitochondria were prepared as published peviously (Rödel et al., 1985) with the following modifications: Cells were washed with $1.25 \mathrm{M}$ sorbitol, 20 $\mathrm{mM} \mathrm{KP}$, and $2 \mathrm{mM}$ EDTA, treated with $100 \mathrm{mM}$ Tris $/ \mathrm{SO}_{4}$ and $5 \mathrm{mM}$ DTT in the presence of $1.25 \mathrm{M}$ sorbitol, and converted to spheroplasts with $1.5 \mathrm{mg}$ of Zymolyase $20000 / \mathrm{g}$ wet weight $\left(20 \mathrm{~min}, 30^{\circ} \mathrm{C}\right)$. After having been washed once with $1.25 \mathrm{M}$ sorbitol, the spheroplasts were spun through a $10-\mathrm{mL}$ cushion of $0.8 \mathrm{M}$ sucrose, $1.5 \%$ Ficoll, and $20 \mathrm{mM}$ HEPES/KOH ( $\mathrm{pH} \mathrm{7.2)} \mathrm{per} \mathrm{gram} \mathrm{wet} \mathrm{weight}\left(15 \mathrm{~min}, 4^{\circ} \mathrm{C}\right.$, $3000 \mathrm{rpm}$; Sorvall, HB4 rotor). After removal of the supernatant with suction, the pellet was resuspended in $30 \mathrm{~mL}$ of $0.6 \mathrm{M}$ mannitol, $20 \mathrm{mM}$ Tris- $\mathrm{HCl}$ (pH 7.2), and $1 \mathrm{mM}$ EDTA per gram wet weight by ten strokes in a loosely fitting Dounce homogenizer. Crude mitochondria were obtained after five differential centrifugation cycles. They were resuspended at $1 \mathrm{mg}$ of protein $/ \mathrm{mL}$ in SEM buffer $(0.25 \mathrm{M}$ sucrose, $0.5 \mathrm{mM}$ EDTA, $20 \mathrm{mM}$ MOPS/KOH, pH 7.4) and layered on top of a $2.5-\mathrm{mL}$ cushion of $28 \%$ Percoll, $0.25 \mathrm{M}$ sucrose, $20 \mathrm{mM}$ MOPS/KOH (pH 7.2), and 0.5 mM EDTA per milligram of protein. After centrifugation $\left(30 \mathrm{~min}, 4^{\circ} \mathrm{C}, 18000 \mathrm{rpm}\right.$; Sorvall, SS34 rotor) mitochondria were withdrawn with a Pasteur pipet from the lower third of the gradient and diluted with four volumes of SEM buffer. Purified mitochondria were pelleted (10 $\mathrm{min}, 4^{\circ} \mathrm{C}, 15000 \mathrm{rpm}$; Sorvall, SS34 rotor) and resuspended in SEM buffer at a final concentration of $10 \mathrm{mg}$ of protein $/ \mathrm{mL}$. All experimental steps following homogenization of the spheroplasts were performed in the presence of a cocktail of protease inhibitors. Final concentrations were $0.25 \mathrm{mM}$ PMSF, $0.1 \mathrm{mg} / \mathrm{mL}$ aprotinin, $50 \mu \mathrm{g} / \mathrm{mL}$ pepstatin $\mathrm{A}, 10 \mu \mathrm{g} / \mathrm{mL}$ antipain, $1 \mathrm{mM}$ leupeptin, $0.1 \mathrm{mg} / \mathrm{mL}$ benzamidine, $0.1 \mathrm{mg} / \mathrm{mL}$ soybean trypsin inhibitor, $200 \mu \mathrm{M} \mathrm{E}-64$, $0.4 \mathrm{mg} / \mathrm{mL}$ bacitracin, and $10 \mu \mathrm{g} / \mathrm{mL} \alpha_{2}$-macroglobulin.

Subfractionation of Mitochondria. Purified mitochondria were treated with $20 \mathrm{mM}$ creatine phosphate, $0.5 \mathrm{mg} / \mathrm{mL}$ creatine kinase, and $0.5 \mathrm{mM}$ ADP $\left(5 \mathrm{~min}, 25^{\circ} \mathrm{C}\right)$. Then, up to $15 \mathrm{mg}$ of mitochondria $(7.5 \mathrm{mg} / \mathrm{mL}$ in SEM buffer) was incubated with $50 \mu \mathrm{M} \mathrm{Ca}^{2+}, 0.5 \mu \mathrm{g} / \mathrm{mg}$ TPA, or other compounds as indicated (the phospholipids and diacylglycerol or analogues were dispersed immediately prior to addition by sonication). The releasing reaction was stopped by addition of EGTA (final concentration $100 \mu \mathrm{M}$ ). Mitochondria were washed by centrifugation through a $1-\mathrm{mL}$ cushion of $0.4 \mathrm{M}$ sucrose, $25 \mathrm{mM}$ MOPS/KOH (pH 7.2), and $1 \mathrm{mM}$ EGTA (10 min, $4{ }^{\circ} \mathrm{C}, 30000$ rpm; Beckman TL-100, swing-out rotor). The pellet was resuspended in the same volume of SEM buffer. "Shocked mitochondria" were obtained after dilution of the suspension with five volumes of $20 \mathrm{mM}$ MOPS/KOH ( $\mathrm{pH}$ 7.2) and gently stirring for $10 \mathrm{~min}$ at $4{ }^{\circ} \mathrm{C}$. After five strokes in a loosely fitting Dounce homogenizer, $0.5 \mathrm{~mL}$ of shocked mitochondria was layered on top of a two-step sucrose gradient (1 $\mathrm{mL}$ of $1.5 \mathrm{M}$ sucrose $/ 1 \mathrm{~mL}$ of $0.4 \mathrm{M}$ sucrose in $25 \mathrm{mM}$ HEPES/KOH, pH 7.4, $150 \mathrm{mM} \mathrm{KCl,} 5 \mathrm{mM}$ DTT, $5 \mathrm{mM}$ $\mathrm{MgCl}_{2}, 0.5 \mathrm{mM}$ EDTA, $0.5 \mathrm{mg} / \mathrm{mL} \mathrm{BSA}$ ) and centrifuged (15 min, $4{ }^{\circ} \mathrm{C}, 50000 \mathrm{rpm}$; Beckman TL-100, swing-out rotor). The upper layer on top of the sucrose $(500 \mu \mathrm{L})$ (intermembrane space) and the interface between the sucrose layers (200 $\mu \mathrm{L}$ ) (mitoplasts) were removed with a Pasteur pipet and diluted with an equal volume of assay buffer $(25 \mathrm{mM}$ HEPES/KOH, pH 7.4, $125 \mathrm{mM} \mathrm{KCl,} 0.25 \mathrm{M}$ sucrose, 0.5 mM 5'-AMP, 0.1 mM EGTA, $7.5 \mathrm{mM} \mathrm{MgCl}_{2}, 15 \%$ glycerol, $0.5 \mathrm{mM}$ DTT, $100 \mu \mathrm{M}$ PMSF). The supernatant fraction was precipitated by addition of an equal volume of $60 \%$ PEG 4000 in $20 \mathrm{mM}$ MOPS/KOH ( $\mathrm{pH} \mathrm{7.2)} \mathrm{and} 1 \mathrm{mM}$ EDTA (15 min, $0{ }^{\circ} \mathrm{C} / 10 \mathrm{~min}, 4^{\circ} \mathrm{C} ; 10000 \mathrm{~g}$ ) and subsequently dissolved in binding buffer ( $25 \mathrm{mM}$ MOPS/KOH, pH 7.2, $100 \mathrm{mM}$ sodium citrate, $5 \mathrm{mM}$ DTT, $5 \mathrm{mM} \mathrm{MgCl}_{2}, 100 \mathrm{mM}$ sucrose, 
$7.5 \%$ ethylene glycol, $1 \mathrm{mg} / \mathrm{mL}$ BSA, $2 \mathrm{mM}$ theophylline, 1 $\mathrm{mM}$ IBMX) at $2.5 \mathrm{mg}$ of protein $/ \mathrm{mL}$. The pellet fraction was layered on top of $0.5 \mathrm{~mL}$ of $0.4 \mathrm{M}$ sucrose in $25 \mathrm{mM}$ HEPES/KOH, pH 7.4, and centrifuged $\left(10 \mathrm{~min}, 4^{\circ} \mathrm{C}, 25000\right.$ rpm; Beckman TL-100, fixed-angle rotor). The pellet was resuspended in binding buffer at $2.5 \mathrm{mg} / \mathrm{mL}$ protein.

cAMP-Binding Assay. Specific binding of cAMP to mitochondria or mitochondrial subfractions was determined by a filter-binding assay (Walton \& Garren, 1970). A total of $250 \mu \mathrm{g}$ of mitochondrial protein in a maximum volume of 125 $\mu \mathrm{L}$ of binding buffer was supplemented with 5\% MEGA 10 (final concentration $0.5 \%)$ and incubated $\left(5 \mathrm{~min}, 10^{\circ} \mathrm{C}\right.$ ). After centrifugation $\left(15 \mathrm{~min}, 4^{\circ} \mathrm{C}, 80000 \mathrm{rpm}\right.$; Beckman TL-100, fixed-angle rotor) the supernatant was removed, diluted with $50 \mu \mathrm{L}$ of $25 \mathrm{mM}$ MOPS/KOH (pH 7.2), $0.5 \mathrm{mM}$ EDTA, $25 \mathrm{mM}$ benzamidine, $0.1 \mathrm{mM} 5^{\prime}$-AMP, $25 \mathrm{mM}$ DTT, $5 \mathrm{mg} / \mathrm{mL}$ BSA, $0.5 \mathrm{mg} / \mathrm{mL}$ aprotinin, $5 \mathrm{mg} / \mathrm{mL}$ antipain, 5 $\mathrm{mM}$ leupeptin, $2.5 \mathrm{mg} / \mathrm{mL}$ pepstatin, and $5 \mathrm{mM}$ IBMX and $25 \mu \mathrm{L}$ of $\left[{ }^{3} \mathrm{H}\right] \mathrm{cAMP}(50 \mathrm{nCi})$, and adjusted with $\mathrm{H}_{2} \mathrm{O}$ to a total volume of $250 \mu \mathrm{L}$. After incubation $\left(15 \mathrm{~min}, 0^{\circ} \mathrm{C}\right), 750$ $\mu \mathrm{L}$ of ice-cold washing buffer ( $20 \mathrm{mM}$ MOPS/KOH, $\mathrm{pH} 7.2$, $100 \mathrm{mM}$ sodium citrate, $1 \mathrm{mM}$ EDTA, $0.5 \mathrm{mM}$ EGTA, 0.2 $\mathrm{mM}$ 5'-AMP, $0.5 \mathrm{mM} \mathrm{MgCl} 2,5 \mathrm{mM}$ DTT, $200 \mu \mathrm{M}$ PMSF, $1 \mathrm{mM}$ theophylline, $2 \mathrm{mM}$ IBMX, 0.1\% MEGA $10,10 \%$ glycerol) was added and the mixture applied to a cellulosic filter (pore size $0.45 \mu \mathrm{m}$ ) under vacuum $(0.2 \mathrm{mbar})$. The filter was washed three times with washing buffer $(2 \mathrm{~mL}$ each) and once with $2 \mathrm{~mL}$ of $70 \%$ ethanol. Vacuum-dried filters were counted for radioactivity in $5 \mathrm{~mL}$ of $0.03 \%$ POPOP $/ 0.5 \%$ $\mathrm{PPO} /$ toluene in a Beckman liquid scintillation counter. From the $\mathrm{cpm}$ value of total cAMP binding, the unspecific cAMP binding occurring in the presence of $25 \mu \mathrm{L}$ of $1 \mathrm{mM}$ unlabeled cAMP was subtracted, and from the difference (usually $700-3500 \mathrm{cpm}$ ), the picomoles of cAMP bound per milligram of protein was calculated. Each value represents the mean of at least four filter-binding assays. The standard deviations are indicated by thin bars in the figures.

Assay of cAMP-Dependent Protein Kinase Activity. Mitochondria in kinase buffer $[25 \mathrm{mM}$ MES/KOH, $\mathrm{pH} 7.0,5$ $\mathrm{mM} \mathrm{MgCl} 2,10 \mathrm{mM}$ DTT, $50 \mu \mathrm{M}$ EDTA, $50 \mu \mathrm{M}$ PMSF, 5 $\mathrm{mM} \mathrm{NaF}, 10 \mathrm{mM}$ glycerol 3-phosphate, $5 \mathrm{mM} \mathrm{NaPP}$ $\left(\mathrm{Na}_{4} \mathrm{P}_{2} \mathrm{O}_{7}\right), 2.5 \mathrm{mM}$ sodium molybdate, $5 \%$ glycerol] plus 0.25 $\mathrm{M}$ sucrose and $0.1 \mathrm{mM}$ IBMX were supplemented with $15 \mu \mathrm{Ci}$ of $\left[\gamma^{-32} \mathrm{P}\right]$ ATP. Half of the mixture received $50 \mathrm{nM}$ cAMP; the other half, $\mathrm{H}_{2} \mathrm{O}$. After incubation $\left(30 \mathrm{~min}, 30^{\circ} \mathrm{C}\right)$, the reaction was terminated by addition of ATP (final concentration $4 \mathrm{mM}$ ), cooling to $0{ }^{\circ} \mathrm{C}$, and incubation with $0.5 \%$ MEGA 10 and an equal volume of quench solution (10\% TCA, $1 \%$ BSA, $1 \%$ SDS, $2 \mathrm{mM}$ ATP, $40 \mathrm{mM} \mathrm{NaH} \mathrm{PO}_{4}, 5 \mathrm{mM}$ $\mathrm{NaH}_{2} \mathrm{P}_{2} \mathrm{O}_{7}, 100 \mathrm{mM} \mathrm{NaF}, 5 \mathrm{mM}$ EDTA) $\left(30\right.$ min, $\left.0^{\circ} \mathrm{C}\right)$. After centrifugation $\left(15 \mathrm{~min}, 0^{\circ} \mathrm{C}\right.$, microfuge) the pellets were washed (once with quench solution, twice with acetone, once with ethanol), dissolved in sample buffer, and analyzed by SDS-PAGE and autoradiography.

Photoaffinity Labeling with 8- $N_{3}-C A M P$. A total of $50 \mu \mathrm{g}$ of mitochondria in $0.25 \mathrm{M}$ sucrose or solubilized total mitochondrial proteins in $1 \%$ MEGA 10 (100000g supernatant) or mitoplasts in $0.1 \mathrm{M}$ sucrose or solubilized mitoplasts in $1 \%$ MEGA 10 (100000 $g$ supernatant) or intermembrane space proteins were supplemented with an equal volume of 2 -fold labeling buffer ( $50 \mathrm{mM} \mathrm{KH}_{2} \mathrm{PO}_{4}, \mathrm{pH} \mathrm{7.1,15 \%} \mathrm{glycerol,} 200$ $\mu \mathrm{M}$ EDTA, $2 \mathrm{mM}$ 5'-AMP, $200 \mu \mathrm{M}$ PMSF, $1 \mathrm{mM}$ DTT, 10 $\mathrm{mM} \mathrm{MgCl}, 2 \mathrm{mM}$ theophylline, $4 \mathrm{mM}$ IBMX) and $20 \mu \mathrm{Ci}$ of $8-\mathrm{N}_{3}-\left[{ }^{32} \mathrm{P}\right] \mathrm{cAMP}(2 \mu \mathrm{M})$. After incubation $\left(5 \mathrm{~min}, 0^{\circ} \mathrm{C}\right)$ in the dark, the sample was irradiated with $\mathrm{UV}_{280}$ on a mi- crotiter plate for $10 \mathrm{~min}$ at $0^{\circ} \mathrm{C}$ (Pomerantz et al., 1975) in the presence of $0.5 \mathrm{mM}$ mercaptoethanol, $2 \mathrm{mM}$ lysine, $2 \mathrm{mM}$ cysteine, $0.1 \mathrm{mM}$ ATP, $0.5 \mathrm{mM}$ 5'-AMP, and $0.1 \mathrm{mM}$ cGMP in a total volume of $125 \mu \mathrm{L}$. Subsequently, $150 \mu \mathrm{g}$ of cytochrome $c(2 \mathrm{mg} / \mathrm{mL})$ and $50 \mu \mathrm{M}$ unlabeled cAMP were added, and the mixtures were centrifuged through a $1-\mathrm{mL}$ column of Sephadex G-10 (equilibrated with labeling buffer). To the eluate $(300 \mu \mathrm{L})$, an equal volume of $10 \%$ TCA was added $\left(30 \mathrm{~min}, 0^{\circ} \mathrm{C}\right)$. After centrifugation $\left(15 \mathrm{~min}, 4^{\circ} \mathrm{C}\right.$, microfuge) the pellet was washed twice with $1 \mathrm{~mL}$ of ice-cold acetone and once with $0.5 \mathrm{~mL}$ of $70 \%$ ethanol, dried under vacuum, resuspended in $50 \mu \mathrm{L}$ of sample buffer (Laemmli, 1970), and analyzed by SDS-PAGE.

Hydrophobic/Hydrophilic Partitioning. The sample was supplemented with an equal volume of $2 \%$ Triton X-114 (in $0.3 \mathrm{M} \mathrm{NaCl}$ and $0.1 \mathrm{M}$ sorbitol/TEA), incubated (30 min, $0^{\circ} \mathrm{C}$ ), and centrifuged $\left(2 \mathrm{~min}, 0^{\circ} \mathrm{C}\right.$, microfuge) (Bordier, 1981). The clear supernatant was warmed up for $2 \mathrm{~min}$ at $4^{\circ} \mathrm{C}$ and then for $10 \mathrm{~min}$ at $37^{\circ} \mathrm{C}$ and spun for $1 \mathrm{~min}$ in a microfuge at room temperature to separate the detergent and aqueous phases.

Analytical Procedures. Published procedures were used for the determination of the following enzyme activities: succinate:cytochrome $c$ oxidoreductase (Lang et al., 1974), fumarase (Racker, 1950), and cytochrome $c$ peroxidase (Djavadi-Ohaniance et al., 1978). Cytochrome $c_{1}$ was assayed by immunodecoration with specific antibodies and ${ }^{14} \mathrm{C}$-labeled protein A (Towbin, 1979; Müller \& Bandlow, 1987a) and densitometry of autoradiograms with an LKB Ultrascan XL laser densitometer. Protein was determined by the method of Bradford (1976). Polyacrylamide gel electrophoresis [5\% acrylamide $(\mathrm{w} / \mathrm{v})$ stacking gels and $12 \%$ or $20 \%$ acrylamide $(\mathrm{w} / \mathrm{v})$ separating gels] was carried out in the presence of SDS and urea (Laemmli, 1970; Ito et al., 1980; Müller \& Zimmermann, 1987). For fluorography ${ }^{3} \mathrm{H}$-containing gels were soaked in sodium salicylate (Chamberlain, 1979), dried under vacuum, and exposed to X-ray films (Kodak X-Omat AR) for $12-72$ h at $-80^{\circ} \mathrm{C}$

\section{RESULTS}

The mitochondrial cAMP receptor (molecular weight 46000 ) which binds cAMP at $0.5-1 \mathrm{pmol} / \mathrm{mg}$ of protein with high affinity $\left(K_{\mathrm{d}}=10^{-9} \mathrm{M}^{-1}\right)$ was found to be located in the inner mitochondrial membrane of the yeast Saccharomyces cerevisiae. The cAMP-binding domain of the receptor faces the intermembrane space (Rödel et al., 1985). cAMP-dependent protein kinase activity was, on the other hand, observed exclusively in the soluble intermembrane space compartment of mitochondria (Müller \& Bandlow, 1987a). In order to resolve this discrepancy in the occurrence of cAMPbinding and of cAMP-mediated effects in different intramitochondrial compartments, we studied whether, under certain conditions, the membrane-bound mitochondrial cAMP-binding protein is converted into a soluble form as has been described for some eucaryotic plasma membrane associated proteins.

Calcium, Phospholipids, and Diacylglycerol (or Analogues), but Not cAMP, Cause a Specific Change in the Intramitochondrial Location of CAMP-Binding Activity. We examined the effects of calcium and various lipids or lipid derivatives on the intramitochondrial distribution of cAMPbinding activity, since it has been reported repeatedly that such compounds affect the intracellular distribution of certain amphitropic proteins. Yeast mitochondria were purified by Percoll gradient centrifugation, which ensures the removal of contaminating cAMP-binding proteins from both the plasma membrane (Jaynes et al., 1980) and the cytoplasm (Sy \& 


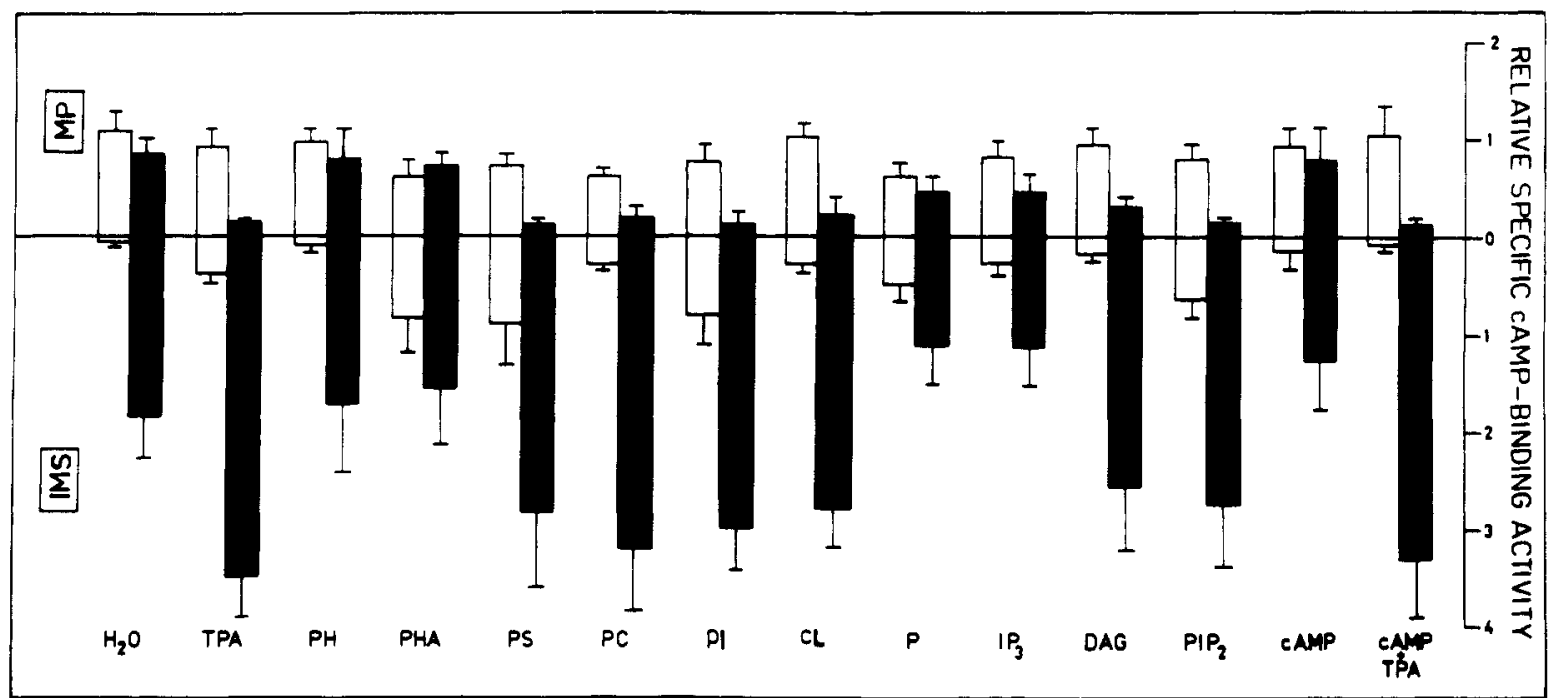

FIGURE 1: Intramitochondrial distribution of the cAMP-binding activity. Aliquots of mitochondria $(5 \mathrm{mg} / \mathrm{mL}$ in SEM buffer plus $100 \mathrm{mM}$ $\mathrm{KCl}, 0.5 \mathrm{mM}$ DTT, and protease inhibitors) were incubated with an ATP-regenerating system with (filled bars) or without (open bars) 50 $\mu \mathrm{M} \mathrm{Ca}{ }^{2+}$ and $100 \mu \mathrm{M}$ cAMP in the presence of lipid compounds. The final concentrations were as follows: TPA, $0.5 \mu \mathrm{g} / \mathrm{mL} ; \mathrm{PH}, 5 \mu \mathrm{g} / \mathrm{mL}$; PHA, $5 \mu \mathrm{g} / \mathrm{mL} ; \mathrm{PS}, 1 \mu \mathrm{g} / \mathrm{mL} ; \mathrm{PC}, 1 \mu \mathrm{g} / \mathrm{mL} ; \mathrm{PI}, 1 \mu \mathrm{g} / \mathrm{mL} ; \mathrm{CL}, 1 \mu \mathrm{g} / \mathrm{mL} ; \mathrm{P}, 5 \mu \mathrm{g} / \mathrm{mL} ; \mathrm{IP}_{3}, 5 \mu \mathrm{g} / \mathrm{mL} ; \mathrm{DAG}, 0.5 \mu \mathrm{g} / \mathrm{mL} ; \mathrm{PIP}, 1 \mu \mathrm{g} / \mathrm{mL}$. Mitochondria were separated into mitoplasts (MP) and intermembrane space (IMS). Both subfractions were assayed for cAMP-binding. The specific cAMP-binding activity of untreated total solubilized mitochondria $(0.28 \mathrm{pmol}$ of $\mathrm{cAMP} / \mathrm{mg}$ of protein) was set as 1 . The relative specific binding activities are shown.

Roselle, 1981). The purity of mitochondria was tested routinely by marker enzyme assays (Rödel et al., 1985; Müller \& Bandlow, 1987a). Typically, isolated mitochondria contained only $3-5 \%$ of total cellular hexokinase activity (a cytoplasmic enzyme), $6-8 \%$ of total cellular catalase activity (a peroxisomal enzyme), and 10-15\% of total membrane-associated alkaline phosphatase or adenylate cyclase activity (enzymes of the plasma membrane) but $75-85 \%$ of total membrane-associated cAMP-binding activity. The specific cAMP-binding activity was about 7 -fold higher in mitochondria isolated from Percoll gradients than in purified plasma membrane preparations [see Müller and Bandlow (1989b)]. These fractionation data confirm the intracellular location of the mitochondrial cAMP receptor protein, which has been demonstrated previously (Rödel et al., 1985). For studying the intramitochondrial location of the binding activity, mitochondria were incubated with the compounds to be tested and subsequently converted to "shocked mitochondria" (mitochondria having disrupted outer membranes). These were separated by centrifugation through a two-step sucrose gradient into mitoplasts (inner-membrane vesicles with adhering outer membrane) and the released soluble intermembrane space proteins. This procedure guarantees the integrity of the mitoplasts as sealed vesicles and their purification from soluble proteins other than those of the mitochondrial matrix. The two mitochondrial subfractions were assayed for cAMPbinding activity by assaying protein-bound $\left[{ }^{3} \mathrm{H}\right]$ cAMP retained on nitrocellulose filters.

It can be seen from Figure 1 that, in the absence of $\mathrm{Ca}^{2+}$, none of the phospholipids was really efficient in altering the intramitochondrial distribution of the specific cAMP-binding activity (open bars). However, as soon as $50 \mu \mathrm{M} \mathrm{Ca}^{2+}$ was also present, a 3-4-fold enrichment of cAMP-binding activity in the intermembrane space was observed (solid bars). Only small differences in the capacity to stimulate specific cAMP-binding activity in the intermembrane space could be detected between the five phospholipids tested $(\mathrm{PC}>\mathrm{CL}>$ $\mathrm{PS}>\mathrm{PI}>\mathrm{PIP}_{2}$ ). On the other hand, $\mathrm{Ca}^{2+}$ alone led only to a 2-fold increase of specific cAMP-binding activity in that compartment $\left(\mathrm{H}_{2} \mathrm{O}\right)$. Of the hydrolysis products of phospholipids $\left(\mathrm{DAG}, \mathrm{IP}_{3}, \mathrm{P}\right)$ only diacylglycerol and the diacyl- glycerol analogue TPA exhibited a $\mathrm{Ca}^{2+}$-dependent increase of cAMP binding in the intermembrane space, the latter being the most effective of all compounds. Physiologically inactive TPA derivatives (phorbol, phorbol acetate) showed no $\mathrm{Ca}^{2+}$-dependent effect in addition to that observed with $\mathrm{Ca}^{2+}$ alone. These findings underline the specificity of TPA in mimicking the phospholpid-induced change in topology of the cAMP-binding activity. Therefore, TPA in the presence or absence of $\mathrm{Ca}^{2+}$ was used in the following experiments. Interestingly, cAMP alone did not affect the intramitochondrial distribution of cAMP-binding activity either alone or in combination with $\mathrm{Ca}^{2+}$ and/or TPA.

The necessity of incubating isolated yeast mitochondria with phospholipids or TPA to yield maximal soluble cAMP-binding activity led to the question whether this could be due to solubilization of the inner mitochondrial membrane. To test this possibility, we assayed the intermembrane space and mitoplast fractions from isolated mitochondria, incubated with or without $\mathrm{Ca}^{2+}$ and/or TPA, for marker proteins of the matrix (fumarase), inner membrane (succinate:cytochrome $c$ oxidoreductase, cytochrome $c_{1}$ ), and intermembrane space (cytochrome $c$ peroxidase). The DeDuve plots in Figure 2 show that the membrane structure remained undisturbed by the treatment with $\mathrm{Ca}^{2+}$ and TPA at the concentrations used. The bulk of both matrix and inner-membrane marker proteins as well as of cytochrome $c$ peroxidase activity copurified with the mitoplast and intermembrane space fractions, respectively, regardless of whether $\mathrm{Ca}^{2+}$ and TPA were present or not. By contrast, the relative specific and total cAMP-binding activities increased in the intermembrane space of mitochondria incubated with $\mathrm{Ca}^{2+}$ and-in a more dramatic fashion-in the presence of $\mathrm{Ca}^{2+}$ and TPA. This increase in the soluble fraction was accompanied by a corresponding decrease in total binding activity in the inner membrane. This inverse relationship of cAMP-binding activity in both compartments provides the first evidence that the membrane-bound cAMPbinding protein is released into the intermembrane space. The total recovery of cAMP-binding activity in mitoplasts and intermembrane space after $\mathrm{Ca}^{2+}$ /TPA treatment of mitochondria was only about $60 \%$. This loss is indicative of either incomplete recovery after the incubation and subfractionation 


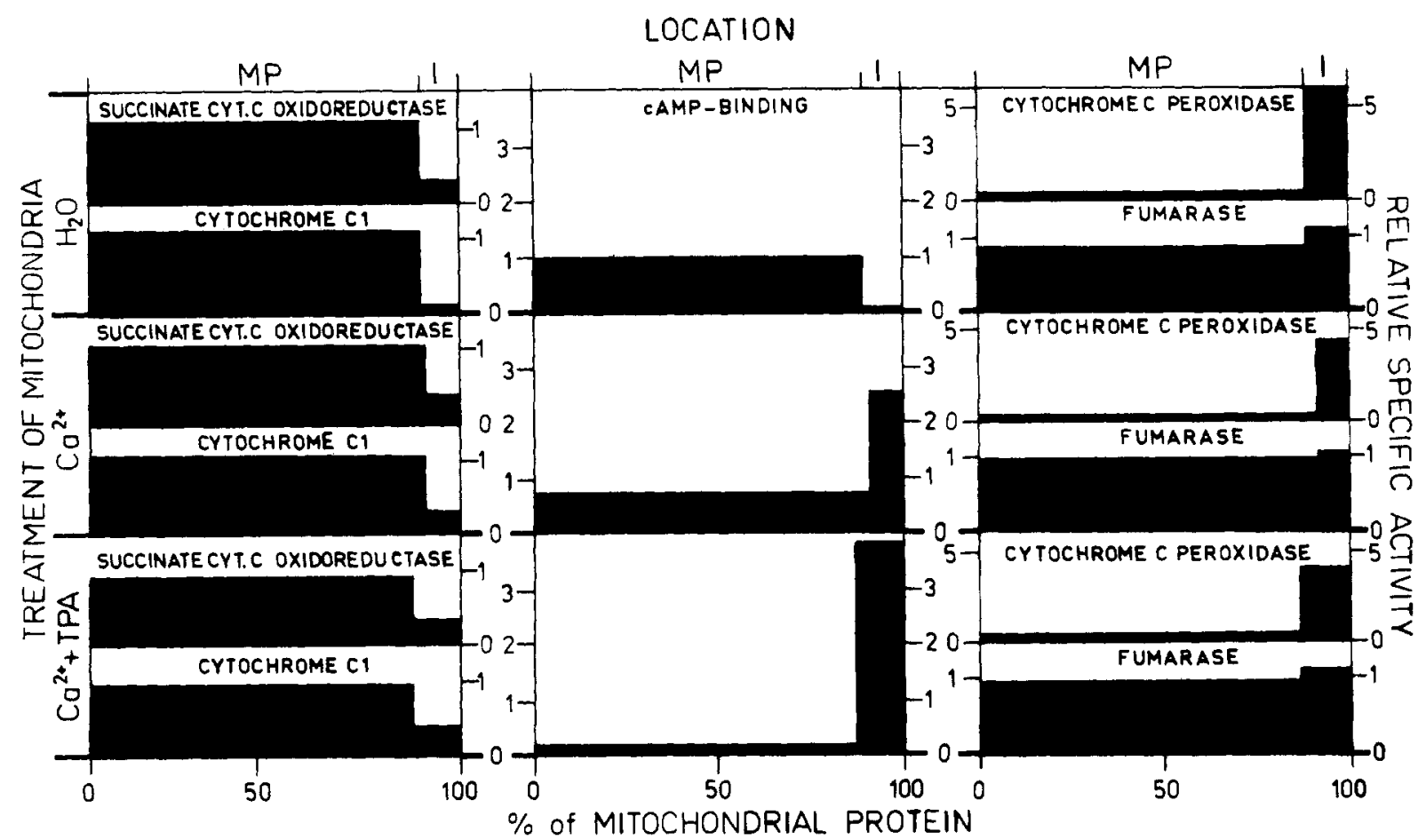

FIGURE 2: Distribution of mitochondrial marker enzymes. The experiment was carried out as described for Figure 1, but in addition to the cAMP-binding activity, the activities of fumarase, cytochrome $c$ peroxidase, and succinate:cytochrome $c$ oxidoreductase were determined. The submitochondrial distribution of cytochrome $c_{1}$ was calculated from the amount of immunoreactive protein. The sum of the protein recovered in the intermembrane space (I) and in the mitoplast fractions (MP) was set as $100 \%$ of the mitochondrial protein. The relative specific activities obtained with solubilized mitochondria not treated with $\mathrm{Ca}^{2+} /$ TPA were set as 1 . The areas of the filled rectangles represent the total activities of the marker enzymes and cAMP-binding protein in the mitoplast or intermembrane space fraction, respectively.

or a reduced binding affinity $\left(K_{\mathrm{d}}\right)$ or a low stability of the CAMP receptor in the presence of $\mathrm{Ca}^{2+}$ and TPA (see below).

Membrane-Bound and Released CAMP-Binding Protein Exhibit the Same Apparent Molecular Weight. Next we wanted to prove that the soluble and membrane-bound cAMP-binding activities originate from the same protein. In the first experiment, we compared the molecular weights of both cAMP-binding proteins. Isolated mitochondria were incubated with various compounds and subsequently separated into mitoplast and intermembrane space fractions, both of which were photoaffinity labeled with $8-\mathrm{N}_{3}-\left[{ }^{32} \mathrm{P}\right] \mathrm{cAMP}$ and analyzed by SDS-PAGE and fluorography. The data shown in Figure $3 \mathrm{~A}$ are in good agreement with those from the filter-binding assay (Figure 1 ). In untreated mitochondria $\left(\mathrm{H}_{2} \mathrm{O}\right)$ a single photolabeled protein of $M_{\mathrm{r}} 46000$ was observed which was exclusively associated with the mitoplast fraction. No such signal could be detected at higher molecular weight in particular $M_{\mathrm{r}} 52000$ (Hixson \& Krebs, 1980), which documents the absence of cross contamination by the cytoplasmic $\mathrm{R}$ subunit in these mitochondrial preparations. In these untreated mitochondria no photoaffinity labeled material could be detected in the intermembrane space (lane 3 ). In the presence of $\mathrm{Ca}^{2+}$ alone, only a small portion of cAMP-binding protein was identified by photoaffinity labeling intermembrane space proteins (lane 6 ), whereas $\mathrm{Ca}^{2+}$ and TPA together led to significant label in this compartment (lane 15) with a concomitant complete loss of label in the mitoplasts (lane 14). The specificity of the combination $\mathrm{Ca}^{2+} / \mathrm{TPA}$ in releasing the cAMP receptor was again emphasized by the lack of effects by TPA alone or phorbol (lanes 9,12 , and 18). The apparent molecular weights of the cAMP-binding proteins recovered from the two different compartments did not differ. [The electrophoretic system would have resolved molecular weight differences of only about $0.5 \mathrm{~K}$ in proteins of about $40 \mathrm{~K}$ (Zimmermann \& Mollay, 1986).]
In the second experiment, we studied the molecular relationship between the two cAMP-binding proteins. Whole mitochondria were labeled with $8-\mathrm{N}_{3}-\left[{ }^{32} \mathrm{P}\right]$ cAMP in the presence or absence of excess unlabeled cAMP and subsequently treated with or without $\mathrm{Ca}^{2+}$ and TPA. After the mitochondria had been fractionated into mitoplasts and intermembrane space proteins, the samples were analyzed by SDS-PAGE (Figure 3B). The mitochondrial cAMP receptor from both compartments bound cAMP specifically as evident from the complete competition of labeling with azido-cAMP by an excess of unlabeled cAMP (lanes 4-6, 10-12, and 16-18). In the presence of $\mathrm{Ca}^{2+}$ alone, most of the photoaffinity labeled protein was recovered from the mitoplast fraction (lane 8 ). Only a minor portion could be observed in the intermembrane space (lane 9 ). The latter compartment was, however, completely devoid of cAMP receptor in the absence of $\mathrm{Ca}^{2+}$ (lane 3 ). $\mathrm{Ca}^{2+}$ in the presence of TPA caused a dramatic increase of photoaffinity labeled material in the intermembrane space (lane 15) with a concomitant decrease in the mitoplasts (lane 14). Photoaffinity labeling prior to incubation with $\mathrm{Ca}^{2+} /$ TPA led to some additional labeled bands, caused probably by proteolytic degradation of the $46 \mathrm{~K}$ cAMP-binding protein despite the presence of a multitude of protease inhibitors. This proteolytic sensitivity would also explain the loss of total CAMP-binding activity in mitochondria treated with $\mathrm{Ca}^{2+} /$ TPA (shown above). Interestingly, the degradation patterns of the labeled fragments were identical in both compartments, inferring a common origin. Again, a signal which could be due to a contaminating cytoplasmic cAMP-binding protein was absent. These findings together with the identical apparent molecular weight $(46 \mathrm{~K})$ of the cAMP receptor in both mitochondrial compartments suggest that, in the presence of $\mathrm{Ca}^{2+}$ /TPA and-to a lesser extent-of $\mathrm{Ca}^{2+}$ alone, the cAMP-binding protein is released from the inner membrane into the intermembrane space. Thus, the 

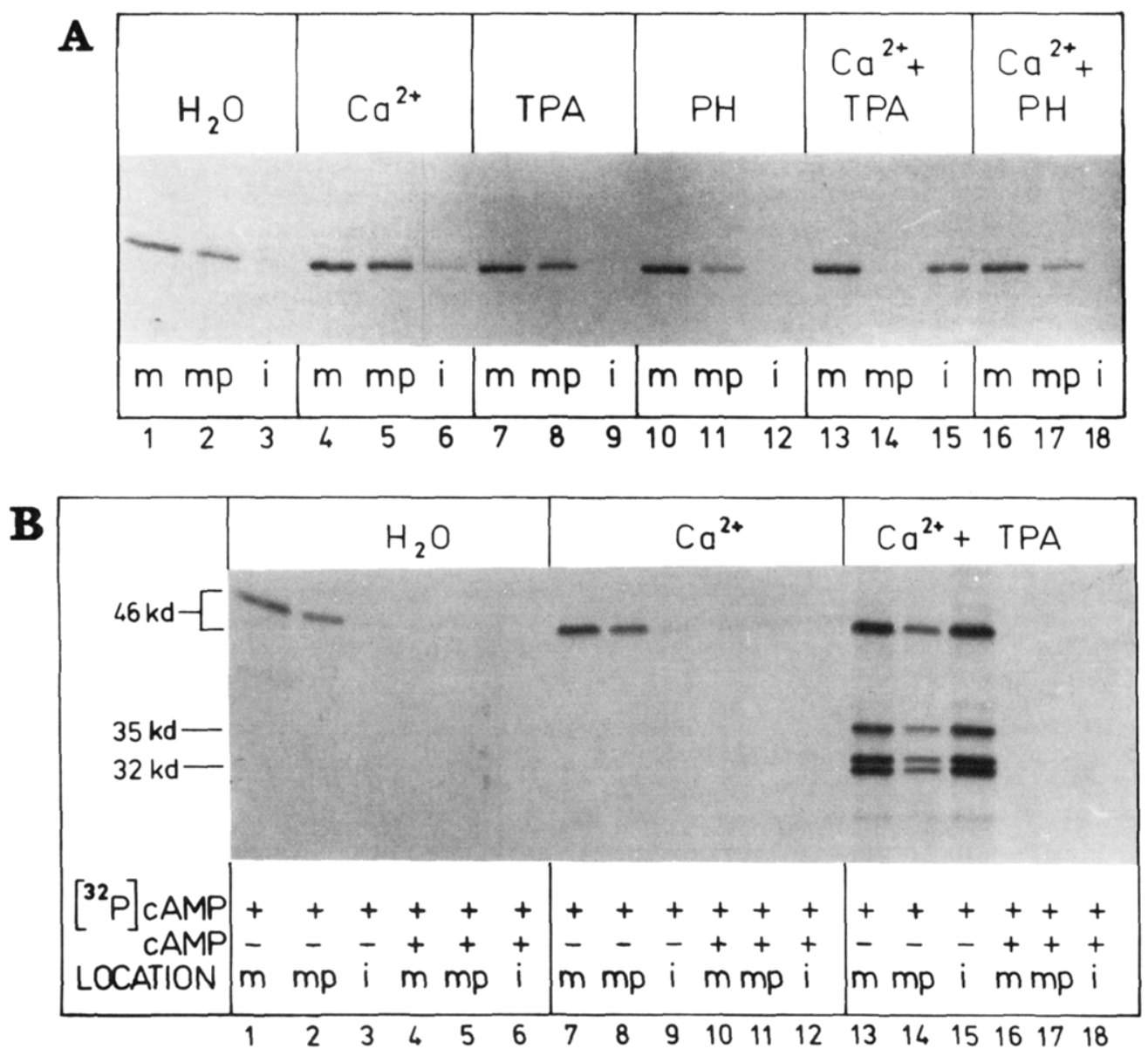

FIGURE 3: Treatment of photoaffinity labeled mitochondria with $\mathrm{Ca}^{2+}$ and phorbol esters. (Panel A) Mitochondria were treated as described for Figure 1. After incubation with $\mathrm{Ca}^{2+}$, TPA, or PH, half of the mitochondria was separated into mitoplasts (mp) and intermembrane space fraction (i). The other half was left on ice as control mitochondria (m). Mitochondria and mitoplasts were centrifuged through a cushion of $0.4 \mathrm{M}$ sucrose. Intermembrane space proteins were precipitated with $30 \%$ PEG $4000.100 \mu \mathrm{g}$ of each sample was photoaffinity labeled with $8-\mathrm{N}_{3}-\left[{ }^{32} \mathrm{P}\right] \mathrm{cAMP}$ in buffer plus $0.5 \%$ MEGA 10 . Subsequently, all samples were precipitated with $5 \%$ TCA and the washed pellets (twice with acetone, once with ethanol) dissolved in sample buffer and analyzed by SDS-PAGE and fluorography. (Panel B) Aliquots of whole mitochondria were photoaffinity labeled in the presence or absence of $200 \mu \mathrm{M}$ unlabeled cAMP before incubation with or without TPA and Ca ${ }^{2+}$. Subsequently, the mitochondria were separated into mitoplasts and intermembrane space proteins and further processed for electrophoretic analysis as described for panel A. The molecular weights were determined by comparison with a molecular weight standard, run in parallel on the same gel.

mitochondrial cAMP receptor of the yeast $S$. cerevisiae exhibits properties of an amphitropic protein.

The conversion of the membrane-bound form into the soluble form of the cAMP-binding protein under preservation of the apparent molecular weight could be most easily explained by a loose association of the receptor with the outer face of the inner membrane as a peripheral membrane protein. To test the nature of the membrane association, isolated mitochondria were photoaffinity labeled, subjected to various extraction procedures, and centrifuged. The resulting pellets and supernatant fractions were counted for radioactivity. Figure 4 shows that the cAMP-binding protein was almost completely released into the supernatant in the presence of detergent. However, extraction by agents capable of releasing peripheral membrane proteins (urea, hydroxylamine, sodium carbonate, or high salt) was ineffective. In a control incubation with $\mathrm{Ca}^{2+} /$ TPA, the cAMP receptor was solubilized to an extent similar to that after detergent treatment. These findings indicate that the membrane-bound cAMP receptor behaves as an integral rather than as a peripheral membrane protein. Since most integral membrane proteins are anchored in the membrane via a stretch of hydrophobic amino acids and since, at the same time, no proteolytic removal of such a structure seemed to have had occurred, we examined how the membrane-embedded form of the amphitropic cAMP-binding protein is rendered soluble.
Two Versions of the cAMP-Binding Protein Differ in Their Conformation and Detergent-Binding Characteristics. The membrane-bound and soluble forms of amphitropic proteins are assumed to differ in their structure due to posttranslational modification and/or in their conformation. We tested the last possibility and examined the relative susceptibility of the released and membrane-associated receptor toward proteolytic digestion by endoprotease V8. Different conformations of a protein should exhibit different protease sensitivities. Photoaffinity labeled released or membrane-bound receptor was dissolved in buffer plus detergent and digested with limiting amounts of protease V8 in both the native (minus SDS/urea) and the denatured state (plus SDS/urea). The electrophoretic analysis of the labeled degradation products is shown in Figure 5. In the absence of SDS and urea the peptide patterns obtained with up to $10 \mu \mathrm{g} / \mathrm{mL}$ protease differed significantly between the membrane-bound form solubilized by detergent (lanes 1-3) and the released form (lanes 6-8), suggesting different conformational states of these proteins. The identity of the peptide patterns generated after denaturation of both forms with SDS/urea supports this view and again emphasizes the similarity or perhaps identity of their primary structures (lanes 11-16). The fact that, after complete digestion of the denatured $46 \mathrm{~K}$ protein, two peptide fragments were observed in about stoichiometric amounts which have retained the photoaffinity label (lanes 13 and 16) may be taken as an 


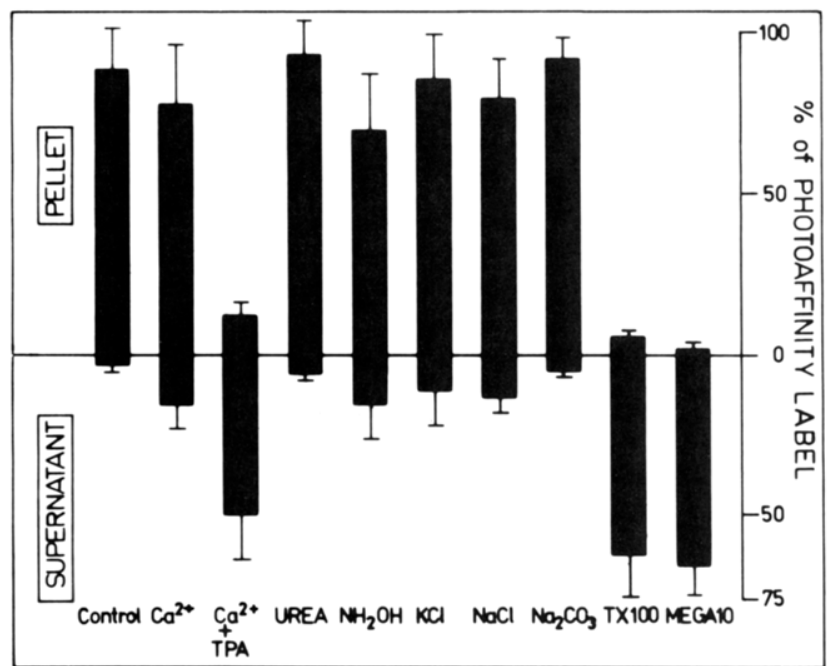

FIGURE 4: Extraction behavior of the cAMP-binding protein. Whole mitochondria $(500 \mu \mathrm{g})$ were labeled with $8-\mathrm{N}_{3}-\left[{ }^{32} \mathrm{P}\right] \mathrm{cAMP}$, converted to shocked mitochondria, and divided into ten aliquots. Two aliquots were incubated with $\mathrm{Ca}^{2+}$ in the presence or absence of TPA. All the other aliquots were centrifuged through $200-\mu \mathrm{L}$ cushions of 0.25 $\mathrm{M}$ sucrose. The resulting pellets were resuspended in either $0.1 \mathrm{M}$ sorbitol/20 mM TEA ( $\mathrm{pH} 7.0$ ) (control) or $6 \mathrm{M}$ urea, $1 \mathrm{M} \mathrm{KCl}, 1$ $\mathrm{M} \mathrm{NaCl}, 1 \% \mathrm{TX}-100$, and $0.5 \%$ MEGA 10 made in $0.1 \mathrm{M}$ sorbitol/TEA or $0.2 \mathrm{M}$ sodium carbonate (in water, $\mathrm{pH} 11.5$ ) or in $1 \mathrm{M}$ hydroxylamine (in water, $\mathrm{pH} \mathrm{7.0)}$ ). After incubation for $15 \mathrm{~min}$ on ice or $60 \mathrm{~min}$ at $37^{\circ} \mathrm{C}$ (hydroxylamine) or $10 \mathrm{~min}$ at $25^{\circ} \mathrm{C}$ $\left(\mathrm{Ca}^{2+} / \mathrm{TPA}\right)$, the samples were spun $\left(60 \mathrm{~min}, 4^{\circ} \mathrm{C}, 250000 \mathrm{~g}\right)$. The supernatants and pellets were boiled in $0.5 \%$ SDS, supplemented with scintillation cocktail, and counted for radioactivity. $100 \%$ of photoaffinity label refers to the cpm measured for $50 \mu \mathrm{g}$ of photoaffinity labeled total mitochondrial protein before the extraction procedure.

indication that the protein has two cAMP-binding sites as observed with all regulatory subunits of cAMP-dependent protein kinases (Takio et al., 1984; Titani et al., 1984).

Different conformations would also explain the finding that in vivo the soluble protein is much more labile than the membrane-associated form. This differential protease sensitivity of the receptor was demonstrated in mitochondria from a wild-type yeast strain and two protease-deficient strains. Mitochondria were isolated, incubated with or without $\mathrm{Ca}^{2+}$ plus TPA, and fractionated into mitoplasts containing membrane-bound receptor and intermembrane space containing soluble receptor. Both forms were incubated at $0^{\circ} \mathrm{C}$ in a detergent-containing buffer and subsequently assayed for cAMP-binding activity. In all three strains the soluble receptor had a shorter half-life than the membrane-bound one, the protein from the wild-type strain being most sensitive (data not shown). This argues that the released receptor has a less compactly folded structure which is more accessible to protease digestion as compared to the solubilized membrane protein. Obviously, liberation of the receptor from the membrane by detergent does not per se result in the conformation of the $\mathrm{Ca}^{2+} /$ TPA-released receptor. This is the first hint at a posttranslational modification causing the conformational change (Müller \& Bandlow, 1989b).

An altered conformation may guarantee the compatibility of the previously membrane-embedded cAMP receptor with the soluble compartment. Therefore, we studied the hydrophobicity of both amphitropic versions by examining their partition equilibrium between an aqueous phase and TX-114. Photoaffinity labeled mitochondria were incubated with phospholipids or lipid derivatives in the presence or absence of $\mathrm{Ca}^{2+}$. Subsequently, the separated mitoplast and intermembrane space fractions were adjusted to $1 \%$ TX-114 and centrifuged. Both pellet and supernatant were assayed for radioactivity. It can be seen from Figure 6 that the membrane-bound cAMP-binding protein $\left(\mathrm{H}_{2} \mathrm{O}\right)$ was found almost exclusively in the detergent phase, wheres the bulk of the released receptor $\left(\mathrm{Ca}^{2+}\right.$ plus phospholipids, TPA, diacylglycerol) was recovered from the aqueous phase. Surprisingly, $\mathrm{Ca}^{2+}$ alone, although solubilizing about $20 \%$ of the total cAMP-binding activity, did not increase the proportion of receptor in the aqueous phase. These results argue that the $\mathrm{Ca}^{2+}$ - plus phospholipid-controlled release of the cAMPbinding protein from the inner membrane is accompanied by a conformational change and decrease in lipophilicity, whereas $\mathrm{Ca}^{2+}$ alone is inefficient in this respect.

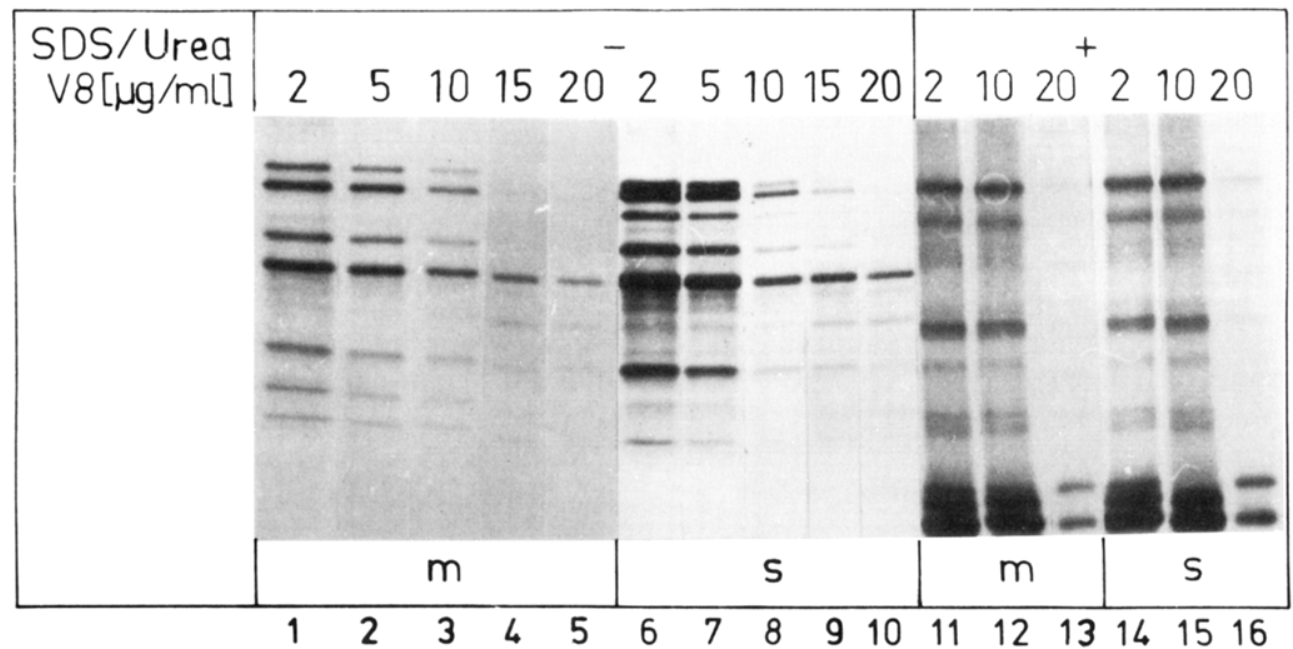

FIGURE 5: Partial proteolysis of membrane-bound and soluble cAMP-binding protein. Aliquots of photoaffinity labeled mitochondria ( 3.2 $\mathrm{mg}$ ) from the yeast strain PEP4-3 were incubated with $\mathrm{H}_{2} \mathrm{O}$ or $\mathrm{Ca}^{2+}$ plus TPA. Reisolated mitochondria were separated into mitoplast and intermembrane space fractions. The mitoplasts derived from the untreated mitochondria were diluted 4-fold with $25 \mathrm{mM}$ MOPS/KOH (pH 7.2 ), collected by centrifugation, and resuspended at $0.5 \mathrm{mg}$ of protein $/ \mathrm{mL}$ in $50 \mathrm{mM}\left(\mathrm{NH}_{4}\right)_{2} \mathrm{CO}_{3}$ buffer (pH 7.8) plus $0.5 \% \mathrm{MEGA} 10$ (m). The intermembrane space proteins derived from the $\mathrm{Ca}^{2+} /$ TPA-treated mitochondria were concentrated 10 -fold by ultrafiltration through an Amicon XM-300 membrane and supplemented with $\left(\mathrm{NH}_{4}\right)_{2} \mathrm{CO}_{3}$. All samples were divided into two halves, one of which received urea $(6$ $\mathrm{M}$ final concentration) and SDS $\left(0.2 \%\right.$ final concentration) and the other $\mathrm{H}_{2} \mathrm{O}$. Aliquots of each half were incubated with $2,5,10,15$, or $20 \mu \mathrm{g} / \mathrm{mL}$ protease V8 from Staphylococcus aureus $\left(60 \mathrm{~min}, 25^{\circ} \mathrm{C}\right)$ in a total volume of $250 \mu \mathrm{L}$. After addition of a 2 -fold molar excess of $\alpha_{2}$-macroglobulin $\left(5 \mathrm{~min}, 0^{\circ} \mathrm{C}\right)$, the samples were precipitated with 5\% TCA, washed twice with acetone, and analyzed by SDS-PAGE (20\%) and fluorography. 


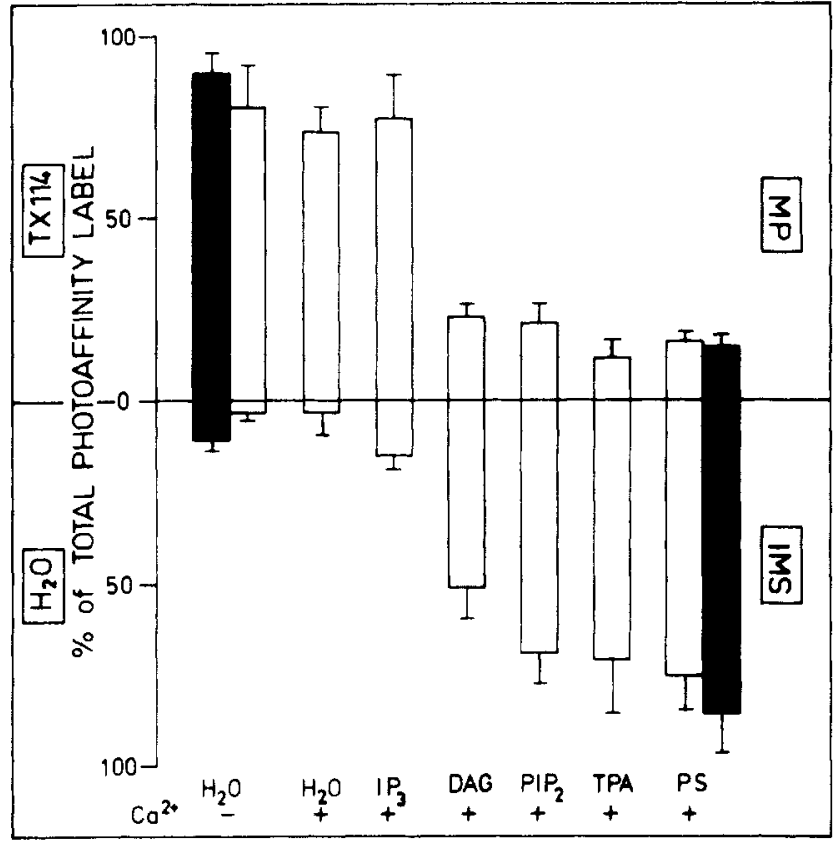

FIGURE 6: TX-114/ $\mathrm{H}_{2} \mathrm{O}$ partitoning of the cAMP-binding protein. Photoaffinity labeled mitochondria $(700 \mu \mathrm{g})$ were incubated as described for Figure 1 and separated into mitoplast and intermembrane space fractions. Mitoplasts (MP) were spun $\left(60 \mathrm{~min}, 4^{\circ} \mathrm{C}, 100000 \mathrm{~g}\right.$ ). Intermembrane space proteins (IMS) were precipitated with $30 \%$ PEG 4000 . Each resuspended pellet $(0.1 \mathrm{M}$ sorbitol, $25 \mathrm{mM}$ TEA) was subjected to hydrophobic/hydrophilic partitioning. Individual phases were boiled in $0.5 \%$ SDS, supplemented with five volumes of scintillation cocktail, and counted for radioactivity. The sum of the cpm measured in both phases of the mitoplast and intermembrane space fractions, respectively, was set as $100 \%$. For comparison the distribution of the photoaffinity label between the two phases is given for two selected incubations of whole mitochondria (filled bars). For reasons of clearity in all other cases, the distribution of radioactivity is given only for the detergent phases of the mitoplasts and for the aqueous phases of the intermembrane space proteins, respectively (open bars). The corresponding aqueous phases of the mitoplast fractions and detergent phases of the intermembrane space fractions contained less than $10 \%$ of the total photoaffinity label and were omitted.

Intramitochondrial Distribution of the CAMP-Binding Protein Changes Also in Vivo. The data presented in favor of the amphitropism of the mitochondrial cAMP receptor were derived from isolated yeast mitochondria incubated in vitro. It was therefore of considerable interest to find out whether this protein changes its intramitochondrial location also in vivo. Since on the one hand phospholipids seem to control the location of the mitochondrial cAMP-binding protein in vitro and on the other hand the lipid composition of intracellular membranes, including those of mitochondria, varies with the growth temperature [for a review, see Daum (1985)], we studied the intramitochondrial distribution of the cAMP receptor in yeast cells cultured at low temperature.

Yeast cells, grown at $30^{\circ} \mathrm{C}$ to midlog phase, were cooled to $10^{\circ} \mathrm{C}$. After various incubation periods mitochondria were prepared and separated into mitoplasts and intermembrane space, and both fractions were assayed for cAMP-binding activity and specific marker proteins. In addition, the partitioning behavior of photoaffinity labeled cAMP-binding protein was analyzed. Figure 7 demonstrates that the intramitochondrial distribution of the cAMP receptor, in fact, changed during prolonged incubation of cells at $10^{\circ} \mathrm{C}$. After $5 \mathrm{~h}$ the protein was nearly equally distributed between mitoplasts and intermembrane space as well as between the detergent and aqueous phases, respectively. By contrast, after growth at $30^{\circ} \mathrm{C}$, the bulk of the receptor was membrane bound. Inherent instability of mitochondria isolated from

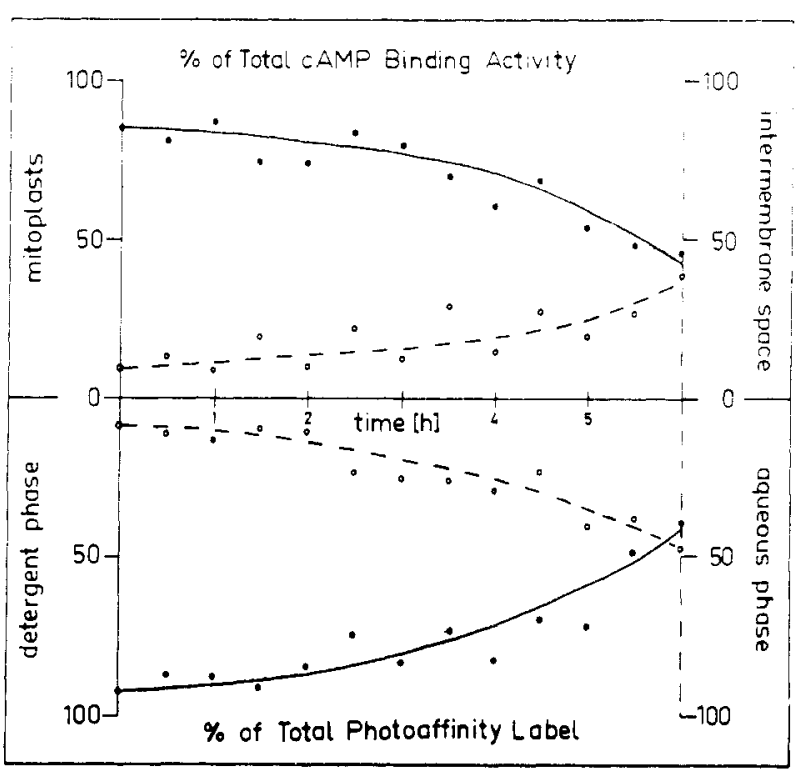

FIGURE 7: Location of the cAMP-binding protein at low temperature in vivo. Lactate-grown $\left(30^{\circ} \mathrm{C}\right)$ cells from the strain PEP4-3 were harvested at a titer of $1.5 \times 10^{6}$ cells $/ \mathrm{mL}$, resuspended in twice the volume of fresh lactate medium, and grown for another $6 \mathrm{~h}\left(30^{\circ} \mathrm{C}\right)$. Harvested cells were resuspended in the same volume of cold lactate medium and incubated with shaking at $10^{\circ} \mathrm{C}$. Aliquots were withdrawn as indicated and cooled to $0^{\circ} \mathrm{C}$, and mitochondria were prepared. Half of them was separated into mitoplasts (solid line) and intermembrane space proteins (broken line). Both fractions were assayed for cAMP binding (upper half). The other half of the mitochondria was photoaffinity labeled and subjected to hydrophobic/hydrophilic partitioning. The detergent (solid line) and aqueous (brocken line) phases were counted for radioactivity (lower half). The total cAMP binding and the total photoaffinity label, respectively, of solubilized mitochondria was set as $100 \%$.

nongrowing yeast cells was excluded since the major portion of fumarase and succinate:cytochrome $c$ oxidoreductase was retained within the mitoplasts for more than $6 \mathrm{~h}$ after the temperature shift (data not shown). It remains unclear whether the altered intramitochondrial distribution of the cAMP receptor is ultimately related to a change in lipid composition of the mitochondrial membranes caused by the temperature shift. Nevertheless, these data suggest that the amphitropism of the cAMP receptor observed in vitro may also play a role in vivo.

Release of the CAMP-Binding Protein Is Accompanied by an Increase in Mitochondrial CAMP-Dependent Protein Kinase Activity. Having established the dual intramitochondrial location of the mitochondrial cAMP-binding protein in vitro and in vivo, the question concerning the functional relevance of this amphitropism arose. In a previous study we observed a cAMP-dependent protein kinase activity in yeast mitochondria located exclusively in the intermembrane space (Müller \& Bandlow, 1987a). However, cAMP-dependent phosphorylation of a $40 \mathrm{~K}$ inner-membrane protein could be demonstrated only after incubation of an excess of isolated intermembrane space proteins with isolated inner-membrane vesicles but not in whole mitochondria. In light of the data presented in this paper it was tempting to speculate that, under physiological conditions, mitochondria would contain only a low steady-state concentration of cAMP receptor in the intermembrane space, only in this compartment it might function as the regulatory subunit of the cAMP-dependent kinase. Consequently, the membrane-bound form of the receptor would be a kind of inactive precursor. To test this possibility we studied the cAMP-dependent protein kinase activity in intact yeast mitochondria in the presence of $\mathrm{Ca}^{2+}$ and TPA. 


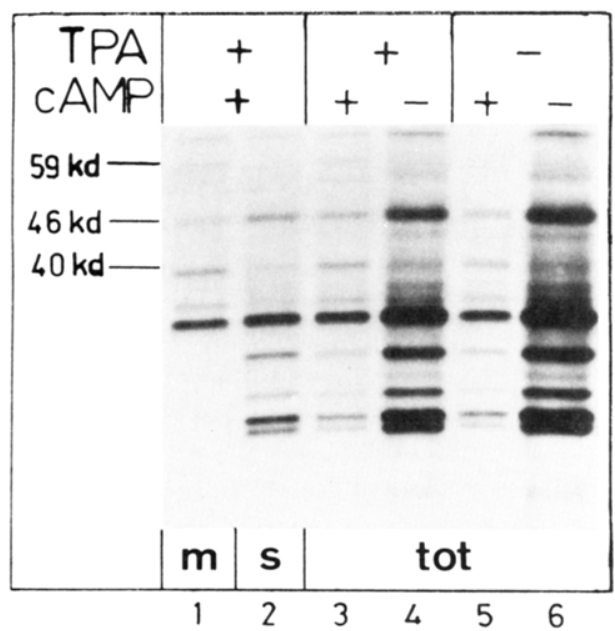

FIGURE 8: Mitochondrial cAMP-dependent protein kinase activity. Four aliquots of intact mitochondria (125 $\mu \mathrm{g}$ each) from strain PEP4-3 were incubated in the presence of $\mathrm{Ca}^{2+}$ with or without TPA, supplemented with EGTA plus phosphatase inhibitors, and reisolated by centrifugation through a cushion of sucrose. Resuspended mitochondria were assayed for cAMP-dependent protein kinase activity. Prior to addition of quench solution the samples were divided into halves. Half was left on ice (tot). The other half was spun $(20 \mathrm{~min}$, $\left.4^{\circ} \mathrm{C}, 50000 \mathrm{~g}\right)$. Resuspended mitochondria $(1 \mathrm{mg} / \mathrm{mL}$ in $25 \mathrm{mM}$ MOPS/KOH, pH 7.2, 1 mM EDTA) were sonicated and separated into soluble proteins (s) and membranes $(\mathrm{m})$ by centrifugation $(30$ min, $4^{\circ} \mathrm{C}, 100000 \mathrm{~g}$ ). For calibration, standard molecular weight markers were run in parallel on the same gel and stained with Coomassie blue (not shown).

Mitochondria were treated with $\mathrm{Ca}^{2+}$ in the presence or absence of TPA, reisolated by centrifugaton, and subsequently incubated with $\left[\gamma^{-32} \mathrm{P}\right]$ ATP in the presence or absence of cAMP. The total incubation mixtures or the separated soluble and particulate fractions were analyzed by SDS-PAGE and autoradiography. Figure 8 shows the complex pattern of phosphoproteins obtained. Surprisingly, we observed a dramatic decrease in total phosphate incorporation in the presence of $20 \mathrm{nM}$ cAMP whether or not the mitochondria had been pretreated with TPA (lanes 3 and 6). Most of the ${ }^{32}$ P-labeled proteins seen were likely to be phosphorylated by extra- and intramitochondrial protein kinases other than the cAMP-dependent species. At least four such enzymes had been described in mitochondria previously, among them a casein kinase II (Müller \& Bandlow, 1987a). In addition, the cAMP-dependent phosphorylation of a $50 \mathrm{~K}$ protein and a $59 \mathrm{~K}$ protein could be detected. It was stimulated $2-3$-fold by the simultaneous presence of $\mathrm{Ca}^{2+}$ and TPA (compare the stimulation factors between lanes 3 and 4 vs those between lanes 5 and 6). Both target proteins were membrane associated (lane 1). The $40 \mathrm{~K}$ phosphoprotein is presumably identical with the inner-membrane protein found to be phosphorylated in a cAMP-dependent fashion in the reconstituted system (Müller \& Bandlow, 1987a). The $\mathrm{Ca}^{2+} /$ TPA-induced stimulation of the cAMP-dependent mitochondrial kinase activity—although not very pronounced-provides the first hint at a new type of kinase activation via regulation of the amphitropism of its regulatory subunit.

The occurrence of the mitochondrial cAMP-binding protein in a complex with a putative catalytic subunit of the mitochondrial cAMP-dependent protein kinase was tested by analyzing its migration behavior in the membrane-bound and soluble states on a native gel. For this purpose mitochondria were incubated with $\mathrm{Ca}^{2+}$ and $\left[\gamma-{ }^{32} \mathrm{P}\right] \mathrm{ATP}$ since it had been shown that the cAMP receptor is phosphorylated in a $\mathrm{Ca}^{2+}$-dependent fashion (Müller \& Bandlow, 1989b). After

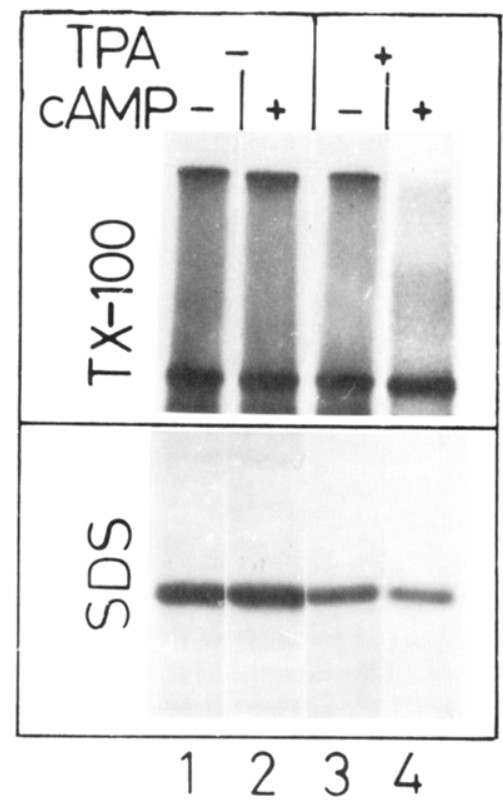

FIGURE 9: Native gel electrophoresis of the cAMP-binding protein. Mitochondria $(400 \mu \mathrm{g})$ were incubated in the presence of $\mathrm{Ca}^{2+}$, [ $\left.\gamma^{32} \mathrm{P}\right]$ ATP $(5 \mu \mathrm{Ci})$, and $0.1 \mathrm{mM}$ IBMX with or without TPA and cAMP $(50 \mathrm{nM})$. After $10 \mathrm{~min}$ at $25^{\circ} \mathrm{C}$, mitochondria were centrifuged through a cushion of $0.4 \mathrm{M}$ sucrose, solubilized in column buffer plus $0.1 \%$ Triton X-100, and subjected to cAMP-Sepharose affinity chromatography (Müller \& Bandlow, 1989b). Half of the protein, eluted with $0.1 \mathrm{M}$ cAMP, was adjusted to $2 \%$ SDS and electrophoresed in the presence of SDS and urea (bottom); the other half was electrophoresed in the presence of $0.01 \%$ Triton X-100 (top). Both gels were fluorographed.

incubation with or without TPA and cAMP, the receptor protein was solubilized with Triton X-100, purified by cAMP affinity chromatography, and analyzed by gel electrophoresis in the native or denatured state.

Figure 9 reveals that, in the absence of cAMP, the membrane-bound form of the ${ }^{32} \mathrm{P}$-labeled cAMP receptor, solubilized by detergent, as well as the released form migrated with two different electrophoretic mobilities on the native gel (TX-100) (lanes 1 and 3). However, in the presence of cAMP the upper minor band at the boundary between the stacking and running gel disappeared in the soluble version (lane 4) by contrast to the membrane-bound one (lane 2). This labeled material presumably represented a high molecular weight complex between the cAMP-binding regulatory subunit and a catalytic subunit. Comigration of both versions of the receptor protein on the denaturing gel (SDS), irrespective of whether cAMP had been added (lanes 2 and 4 ) or not (lanes 1 and 3), provided further evidence for complex formation. Obviously, a portion of this complex disassembled also in the presence of Triton X-100 alone, since some phosphorylated receptor migrated into the running gel, presumably as monomer (lower major band), also in the absence of cAMP (lanes 1 and 3) or TPA (lane 2). Nevertheless, this experiment suggests that the mitochondrial cAMP receptor interacts noncovalently with another protein, most likely the catalytic subunit of the mitochondrial cAMP-dependent protein kinase. Release of the complex from the inner membrane seems to be a prerequisite for the subsequent cAMP-dependent dissociation into its subunits and activation of the kinase.

\section{DISCUSSION}

Three different locations have been described in the literature for cAMP-binding proteins in yeast: a soluble $\mathrm{R}$ subunit of a soluble protein kinase A was found in the cytoplasm of 
this organism (Hixson \& Krebs, 1980), several such proteins were described to be associated with the plasma membrane (Jaynes et al., 1980), and one species was detected in mitochondria (Rödel et al., 1985). Apart from location, these proteins differ in molecular weight: $52 \mathrm{~K}$ was reported for the cytosolic $\mathrm{R}$ subunit, $46 \mathrm{~K}$ for the mitochondrial version, and $25 \mathrm{~K}, 34 \mathrm{~K}, 46 \mathrm{~K}$, and $58 \mathrm{~K}$ for the species from the plasma membrane. In agreement with this latter report, we observed cAMP binding in plasma membrane preparations which accounts for a minor portion of the total membrane-associated cAMP-binding activity in yeast cells (Rödel et al., 1985). But, in contrast to the earlier observations (Jaynes et al., 1980), we could detect only a single species of $M_{\mathrm{r}} 44000$ in yeast plasma membranes. Its lower molecular weight and its failure to be released from the membrane by treatment with $\mathrm{Ca}^{2+}$ / TPA in vitro, the biosynthetic incorporation of glutamine, and its inability to become metabolically labeled by stearic acid in vivo (Müller \& Bandlow, 1989a; Bandlow \& Müller, in preparation) argue that this species is distinct from the cAMP-binding protein described here both in structure and in their type of membrane anchor. Accordingly, the low cross contamination by plasma membranes of the mitochondrial preparations (about $<15 \%$ ) does not interfere with the observations reported here. In addition, we verified that the soluble cytoplasmic $\mathrm{R}$ subunit $(52 \mathrm{~K})$ was absent from our mitochondrial preparations. In summary, we detected three separate cAMP-binding proteins in yeast, one of which has been shown to occur in mitochondria (Rödel et al., 1985; Müller \& Bandlow, 1987a). Their genetic relationship remains to be elucidated.

A large body of experimental data documents the amphitropic character of the mitochondrial cAMP receptor of yeast. First, in the presence of calcium together with certain phospholipids or lipid derivatives the cAMP-binding activity increases dramatically in the intermembrane space of isolated mitochondria with a concomitant decrease in the inner membrane. Second, under the same conditions photoaffinity labeled receptor disappears from the inner membrane and emerges in the intermembrane space. Third, according to their electrophoretic mobility both binding proteins have the same appparent molecular weight and share identical electrophoretic patterns of azido-cAMP-labeled peptides after partial proteolysis of the denatured protein. This suggests that the membrane-bound and soluble mitochondrial cAMP receptors are two forms of the same protein with no or only very minor differences in their primary structures. However, both versions exhibit different conformations and possibly posttranslational modifications, as was indicated by two independent criteria: accessibility for proteases of the native proteins and lipophilicity. The structural basis for variation of these properties is elucidated in an accompanying paper (Müller \& Bandlow, 1989a). Fourth, movement of the cAMP-binding protein from the inner membrane into the intermembrane space is also observed in vivo. Thus, the described cAMP receptor provides the first example of an amphitropic protein in mitochondria.

We observed an amazing lack of specificity of phospholipids effecting the release of the membrane-embedded protein. Since lipid head groups alone, e.g., $\mathrm{IP}_{3}$, have no effect, whereas diacylglycerol and especially its nonhydrolyzable analogue TPA, are highly active, the capability of the activator molecule to interact spontaneously with the lipid bilayer may be critical. The importance of hydrophobicity is supported by the fact that phorbol or phorbol acetate, TPA derivatives lacking the myristic acid ester, is incompetent in releasing the receptor, thus emphasizing the necessity of fatty acid side chains.
However, it remains to be clarified which phospholipid or lipid derivative acts in vivo and, in addition, from which cellular membrane it is derived.

Lipid compounds are not an absolute prerequisite for the releasing process. They drastically increase its efficiency, provided $\mathrm{Ca}^{2+}$ is present at concentrations approximately found in the cytoplasms of eukaryotic organisms (McCormack \& Denton, 1986). On the other hand, calcium alone converted only a limited portion of the membrane-bound CAMP receptor into a soluble form. Surprisingly, it was observed that this form of released binding protein does not exhibit decreased lipophilicity. It is unknown whether the $\mathrm{Ca}^{2+}$, regulating the amphitropism in vivo, originates from the endoplasmic reticulum or the mitochondrial matrix, compartments considered as intracelluluar calcium stores (Wang \& Waisman, 1979). In an accompanying paper (Müller \& Bandlow, 1989b) we studied whether the $\mathrm{Ca}^{2+}$-induced and the $\mathrm{Ca}^{2+}$ /phospholipid-induced releases are two mechanistically different processes or whether there exists only a unique releasing pathway wherein $\mathrm{Ca}^{2+}$ and phospholipids affect successive steps.

Eukaryotic cAMP-binding proteins are thought to act exclusively as regulatory subunits of cAMP-dependent protein kinases (Kuo \& Greengard, 1969; Greengard, 1978; Cohen, 1982). This assumption is strengthened by the identification of a unique mitochondrial cAMP receptor and mitochondrial cAMP-dependent protein kinase activity in yeast (Müller \& Bandlow, 1987a). In detail, it was reported that almost all of the mitochondrial CAMP-binding protein was tightly bound to the inner membrane, whereas cAMP-dependent protein kinase was observed exclusively in the soluble intermembrane space, phosphorylating a $40 \mathrm{~K}$ inner-membrane protein. This indicates the simultaneous presence of $R$ and $C$ subunits in this compartment. The findings reported here nicely explain the former discrepancy in that both forms of cAMP-binding activity are derived from the same protein, but only the soluble version behaves as an $R$ subunit of a protein kinase $A$. This implies that the $C$ subunit is bound to $R$ also in the membrane-embedded state of $\mathrm{R}$ and is dissociable by cAMP only upon release from the membrane of the regulatory subunit. Consequently, the cAMP-dependent kinase would be active only in the soluble state.

As shown in this study, the stimulation of the mitochondrial cAMP-dependent kinase by cAMP is moderately enhanced in the presence of $\mathrm{Ca}^{2+}$ plus TPA. This $\mathrm{Ca}^{2+} /$ TPA-induced kinase activation may be masked by rapid dephosphorylation as part of a downregulation of physiological short-term stimulations. Dissociation of $\mathrm{C}$ from the $\mathrm{Ca}^{2+} / \mathrm{TPA}$-released but not from the membrane-embedded or detergent-solubilized $R$ subunit, coisolation of $\mathrm{R}$ and $\mathrm{C}$ by affinity chromatography after solubilization by mild detergents, and the occurrence of casein kinase activity in the eluate (W. Bandlow, unpublished observations) supply additional evidence for the assumption that $\mathrm{R}$ is associated with $\mathrm{C}$ also in the membrane-bound state. The membrane-bound and the soluble forms of the $\mathrm{R}$ subunit were shown to bind CAMP. Obviously, the altered conformation (and lipophilicity) of the released $\mathrm{R}$ is a prerequisite for its cAMP-dependent dissociation from $C$.

The physiological role of the mitochondrial cAMP-dependent protein kinase activity is not yet known. It has, however, repeatedly been communicated that cAMP has some bearing on yeast mitochondrial biogenesis (Chandrasekaran \& Jayaraman, 1978; Mahler \& Lin, 1978) and respiration (Fang \& Butow, 1970). Recently it was noticed that ras 1 , ras2 double mutants, which have very low endogenous cAMP (Temeles et al., 1985), exhibit a respiratory-deficient phe- 
notype (Fraenkel, 1985; Tatchell et al., 1985) whereas overproduction of the cyclic nucleotide in RAS $^{\text {val19 }}$ mutants results in giant mitochondria (J. Mattoon, personal communication) capable of enhanced respiration (Kataoka et al., 1984; Toda et al., 1985). So, it may be speculated that mitochondrial protein kinase $A$ is involved in the modulation of cAMP-dependent effects on mitochondria. It might fulfill an essential role like all second messenger-linked kinases found so far [for a review, see Krebs and Beavo (1979) and Pall (1981)] by somehow controlling the biogenesis of mitochondria as a component of a complex signal transduction pathway between the cytoplasm and mitochondria. The direct control by this kinase of mitochondrial transcription, translation, or import of proteins into mitochondria is, however, unlikely (Müller \& Bandlow, 1987b).

Registry No. IP 3 , 85166-31-0; PH, 26241-63-4; PHA, 70470-59-6; 12-myristoyl-PHA, 16561-29-8; PS, 40290-42-4; PC, 63-89-8; DAG, 30334-71-5; $\mathrm{Ca}, 7440-70-2$; protein kinase, 9026-43-1.

\section{REFERENCES}

Achsteter, T., Emter, O., Ehmann, C., \& Wolf, D. H. (1984) J. Biol. Chem. 295, 13334.

Bennet, M. K., Erondu, N. E., \& Kennedy, M. B. (1983) J. Biol. Chem. 258, 12735.

Bordier, C. (1981) J. Biol. Chem. 256, 1604.

Bradford, M. M. (1976) Anal. Biochem. 72, 248.

Burn, P. (1988a) Trends Biochem. Sci. 13, 79.

Burn, P. (1988b) J. Cell. Biochem. 36, 15.

Burn, P., \& Burger, M. M. (1987) Science 235, 476.

Burridge, K. (1986) Cancer Rev. 4, 18.

Chamberlain, J. P. (1979) Anal. Biochem. 98, 132.

Chandrasekaran, K., \& Jayaraman, J. (1978) FEBS Lett. 135, 93.

Cohen, P. (1982) Nature 296, 613.

Daum, G. (1985) Biochim. Biophys. Acta 822, 1.

Daum. G., Böhni, P. C., \& Schatz, G. (1982) J. Biol. Chem. 257, 13028.

Djavadi-Ohaniance, L., Rudin, Y., \& Schatz, G. (1978) J. Biol. Chem. 253, 4402.

Fang, M., \& Butow, R. A. (1970) Biochem. Biophys. Res. Commun. 41, 1579.

Fraenkel, D. (1985) Proc. Natl. Acad. Sci. U.S.A. 82, 4740.

Geiger, B. (1985) Trends Biochem. Sci. 10, 456.

Goud, B., Salminen, A., Walworth, N. C., \& Novick, P. J. (1988) Cell 53, 753.

Greengard, P. (1978) Science 199, 146.

Hemmings, B. A., Zubenko, G. S., Hasilik, A., \& Jones, E. W. (1981) Proc. Natl. Acad. Sci. U.S.A. 78, 435.

Hershenon, S., \& Ernst-Funberg, M. L. (1983) Biochim. Biophys. Acta 751, 412.

Hixson, C. S., \& Krebs, E. G. (1980) J. Biol. Chem. 255, 2137.

Imajoh, S., Kawasaki, H., \& Susuki, K. (1986) J. Biochem. $100,633$.

Ito, K., Date, T., \& Wickner, W. (1980) J. Biol. Chem. 255, 2123.

Jaynes, P. K., McDonough, J. P., \& Mahler, H. R. (1980) Biochem. Biophys. Res. Commun. 94, 16.

Kataoka, T., Powers, S., McGill, C., Fasano, O., Strathern, J., Broach, J., \& Wigler, M. (1984) Cell 37, 437.

Kishimoto, A., Takai, Y., Mori, T., Kikkawa, U., \& Nishizuka, Y. (1980) J. Biol. Chem. 255, 2273.
Kishimoto, A., Najikawa, N., \& Nishizuka, Y. (1983) J. Biol. Chem. 258, 1156.

Kraft, A. S., \& Anderson, N. B. (1983) Nature 301, 621.

Krebs, E. G., \& Beavo, J. A. (1979) Annu. Rev. Biochem. 48, 923.

Kuo, J. F., \& Greengard, P. (1969) Proc. Natl. Acad. Sci. U.S.A. 64, 1349.

Laemmli, U. K. (1970) Nature 227, 680.

Lang, B., Burger, G., Doxiadis, I., Thomas, D. Y., Bandlow, W., \& Kaudewitz, F. (1977) Anal. Biochem. 77, 110.

Lassing, I., \& Lindberg, U. (1985) Nature 314, 472.

Lassing, I., \& Lindberg, U. (1988) J. Cell. Biochem. 37, 255.

Mahler, H. R., \& Lin, C. C. (1978) Biochem. Biophys. Res. Commun. 61, 963.

McCormack, J. G., \& Denton, R. M. (1986) Trends Biochem. Sci. 11, 258.

Müller, G., \& Bandlow, W. (1987a) Yeast 3, 161.

Müller, G., \& Bandlow, W. (1987b) Z. Naturforsch. 42C, 1291.

Müller, G., \& Zimmermann, R. (1987) EMBO J. 6, 2099.

Müller, G., \& Bandlow, W. (1989a) Biochemistry (second paper of three in this issue).

Müller, G., \& Bandlow, W. (1989b) Biochemistry (third paper of three in this issue).

Nigg, E. A., Schäfer, G., Hilz, H., \& Eppenberger, H. M. (1985a) Cell 41, 1039.

Nigg, E. A., Hilz, H., Eppenberger, H. M., \& Duty, F. (1985b) EMBO J. 4, 2801.

Niggli, V., \& Berger, M. M. (1987) J. Membr. Biol. $100,97$.

Nishizuka, Y. (1986) Science 225, 1365.

Pall, M. L. (1981) Microbiol. Rev. 45, 462.

Pomerantz, A. H., Rudolph, S. A., Haley, B. E., \& Greengard, P. (1975) Biochemistry 14, 3858.

Racker, E. (1950) Biochim. Biophys. Acta 4, 211.

Rödel, G., Müller, G., \& Bandlow, W. (1985) J. Bacteriol. $161,7$.

Rotman, A., Heldman, J., \& Linder, S. (1982) Biochemistry $21,1713$.

Schatz, G., \& Mason, T. L. (1974) Annu. Rev. Biochem. 43, 51.

Sy, J., \& Roselle, M. (1981) FEBS Lett. 135, 93.

Takio, K., Smith, S. B., Krebs, E. G., Walsh, K. A., \& Titani, K. (1984) Biochemistry 23, 4200.

Tatchell, K., Robinson, L. C., \& Breitenbach, M. (1985) Proc. Natl. Acad. Sci. U.S.A. 82, 3785.

Temeles, G. L., Gibbs, J. B., D’Alonzo, J. S., Sigal, I. S., \& Scolnick, E. M. (1985) Nature 313, 700.

Terce, F., Record, M., Ribbes, G., Chap, H., \& Douste-Blazy, L. (1988) J. Biol. Chem. 263, 3142.

Titani, K., Sasagawa, T., Ericsson, L. H., Kumar, S., Smith, S. B., Krebs, E. G., \& Walsh, K. A. (1984) Biochemistry 23, 4193.

Toda, T., Uno, T., Ishikawa, S., Powers, S., Kataoka, D., Broek, D., Cameron, S., Broach, J., Matsumoto, K., \& Wigler, M. (1985) Cell 40, 27.

Towbin, H., Staehelin, T., \& Gordon, J. (1979) Proc. Natl. Acad. Sci. U.S.A. 76, 4350.

Walton, G. M., \& Garren, L. D. (1970) Biochemistry 9, 4223.

Wang, J. H., \& Waisman, D. M. (1979) Curr. Top. Cell. Regul. 15, 47.

Zimmermann, R., \& Mollay, C. (1986) J. Biol. Chem. 261, 12889. 